\title{
Välfärdsstaten och det ekonomiska sammanbrottet: Föreställningar om prestation, deltagande och social rättvisa
}

\author{
BRIGITTE AULENBACHER \& BIRGIT RIEGRAF ${ }^{\mathrm{I}}$
}

Sedan 1990-talet har den ekonomiska utvecklingen gått mot att marknaden fätt ett större inflytande, något som också förändrat hur vi tänker om till exempel vad en människa är. Denna artikel diskuterar vad detta fär för konsekvenser för välfärdsstaten, hur innebörder i begrepp som prestation och rättvisa förändrats.

\section{Introduktion}

Statlig inblandning har varit en integrerad del av den keynesianska välfärdsstaten under den fordistiska tidsperioden av det kapitalistiska samhället, där syftet var att balansera ekonomin och de sociala frågorna

Prof. Dr. Brigitte Aulenbacher, Institut für Soziologie, Abteilung für theoretische Soziologie und Sozialanalysen, Johannes Kepler Universität Linz.

Prof. Dr. Birgit Riegraf, Fakultät für Kulturwissenschaften, Allgemeine Soziologie, Universität Paderborn. samt minska socialpolitiska konflikter. Denna typ av tänkande fick minskad betydelse och blev utagerat under 1980-talet och speciellt under 1990-talet när nyliberalismen stärkte sitt inflytande i samhället. Marknadskrafterna har alltmer övertagit statens roll för att skapa balans mellan ekonomiska och sociala frågor. Det är en utveckling som påverkade, och fortfarande påverkar, grundläggande fundamentala

1 Översättning efter överenskommelse med författarna: Elisabeth Berg.

Brigitte Aulenbacher \& Birgit Riegraf: Välfärdsstaten och det ekonomiska sammanbrottet. 
frågor om den samhälleliga reproduktionen. Den söker inte minst svar på frågor som i vilken utsträckning, på vilket sätt och med vilken avsikt välfärden ${ }^{2}$ ska administreras av den offentliga sektorn och vem som har rätt till stöd.

Vi inleder artikeln med att betrakta fordismens historia fram till den finansiella krisen (2). Nästa avsnitt handlar om rationaliseringen av public subsistence welfare (3). Det följs av en beskrivning av dagens läge inom vård och socialt arbete (4), som i sin tur leder oss över till en reflektion över idéer kring genomförande och social rättvisa (5). Artikeln avslutas med en sammanfattning och slutsats (6).

\section{Från fordism till marknadskapitalism}

I Robert Castels (2000) sociologiska rekonstruktion av historien om avlönat arbete poängterade han att den samhälleliga utvecklingen från 1950 till mitten av 1970 var en oöverträffad period som utmärkte sig jämfört med den tidigare och efterföljande kapitalistiska utvecklingen i Västeuropa. Ekonomisk tillväxt och teknologisk utveckling var i högsta grad, så tidigt som 1920, kopplat till löftet om allmänt välstånd (se Hirdman 1995, Schweitzer

2 Författarna har använt begreppet Public subsistence welfare när de beskriver offentlig välfärd och redaktionen vill behålla det engelska begreppet i översättningen. Subsistence är ett vanligt förekommande uttryck för den konservativa välfärdsmodellen som betyder att det $i$ första hand är familjen och det sociala nätverket som ska säkerställa välfärden.
1995, Siegel 1993) - ett löfte som endast förverkligades till viss del efter krigen (se Castel 2000). Ansvaret för en välfärd, som tidigare byggde på privata ideella tjänster eller på stöd från privata företag och andra offentliga uppdrag, utvecklas därefter mot ett keynesianskt mönster inom ett välfärdsstatligt ramverk.

Speciellt den reformorienterade perioden från slutet av 1960-talet till mitten av 1970-talet kännetecknades av en hög investeringsnivå inom den offentliga sektorn, finansierad av offentliga inkomster som skapats av en stabil tillväxtorienterad utveckling av ekonomin med ett stort antal arbetstillfällen, vilket tillät fler grupper i samhället att delta i utbildning och social välfärd (se Negt 2001, Kohlmorgen 2004). Samtidigt utgick denna välfärdsmodell, nedan kallad den konservativa, från att familjer, och speciellt kvinnor som i större eller mindre utsträckning hade ett avlönat arbete, skulle tillhandahålla service som inte ombesörjdes eller inte beaktades av den offentliga verksamheten. Omfattningen av detta skiljer sig mellan länder, men tydliga exempel på detta är vård av barn och unga, såsom daghem och fritidshem.

Denna omstrukturering - där fast anställning ${ }^{3}$, familj och välfärdsstat ingår, inklusive en inbäddad genusordning - var speciell för fordismen. Detta var dock organiserat på skilda sätt i olika västeuropeiska länder, det vill säga utifrån olika välfärdsmodeller. I Sverige användes den "socialdemokratiska modellen", där väl-

\footnotetext{
3 Normal employment har översatts till fast anställning.
} 
färd var mycket tydligt formaliserad genom att staten ansvarade för välfärdsservice till medborgarna. I den "konservativa» välfärdsmodellen, som Tyskland, Österrike och Schweiz representerar, betonas betydelsen av den traditionella kärnfamiljens insatser. Således hade kvinnor en hög förvärvsfrekvens i den första modellen och låg sådan i den andra (Esping-Andersen 1990, Pfau-Effinger 1994). I den »liberala modellen« var den dominerande formen välfärdsservice riktad till familjen, vilket dock inte nödvändigtvis alltid var jämnt fördelat $i$ relation till social klass eller social position. I exempelvis Storbritannien riktades statligt stöd genom vård eller social service bara till den fattiga delen av befolkningen. I USA, där idén om välfärd i huvudsak är en privat fråga, har det uppstått en situation där människor som är ekonomiskt välbeställda ofta skapat en illegal ekonomi. Länge har det alltså varit vanligt i det amerikanska samhället att en kvinnlig immigrant är illegalt anställd i familjen (Riegraf \& Theobald 2010, Graham 1991, Burau et al. 2007). Samtidigt utvecklas i stater med en påtvingad socialism en modifierad variant av fordismen, enligt principerna för den centralt styrda ekonomin där staten tog på sig ansvaret för olika uppgifter som tidigare varit familjens (se Aulenbacher 2007, Dölling 2003).

Dessa olika modeller och modifieringar är knutna till Gösta Esping-Andersens (1990) idéer om hur social rättvisa skapas i olika samhällen: det bygger på utförande i den liberala modellen, på deltagande $i$ den konservativa modellen och på behov $\mathrm{i}$ den socialdemokratiska modellen, och där var och en blir relevant på sitt eget sätt $\mathrm{i}$ olika länder. I den statligt påtvingade socialismen lades stor vikt vid garantier för att överleva, som tillgång till arbete, bostad, medicinsk vård och socialt stöd, något som åtminstone teoretiskt skulle nå ut till alla samhällsmedborgare (se Beer \& Chalupsky 1993).

Den fordistiska organiseringen av fast anställning, kärnfamilj och välfärdsstat har dock sedan mitten av 1970-talet förändrats så att olika länder gått i skilda riktningar. Förändringarna kan indelas $i$ två faser.

Den första fasen är från mitten av 1970talet till slutet av 1980-talet. Den kan med Oskar Negts (2001) ord beskrivas som en "crisis of erosion". I detta ekonomiskt dynamiska sammanhang synliggörs ett gradvist tillbakavisande av fast anställning till förmån för mer flexibla anställningsformer. Kvinnor får ett ökat tillträde till utbildning och ökade möjligheter till anställning. Deras formella och lagligt reglerade jämställdhet leder, tillsammans med andra processer, till en förlust av familjens normativa makt och dess institutionella stabilitet. Denna utveckling skapar utrymme för utveckling av skilda livsstilar. Detta ersätter dock inte välfärdsstaten eftersom det som sker fortfarande är ett skede av välfärdsstatens expansion (se Kohlmorgen 2004).

Inspirerad av regleringsteorin kallas den andra fasen "marknadskapitalismen«. Denna fas inleddes då den statligt påtvingade socialismen kollapsade och den tidigare nämnda organiserade välfärdstaten övergavs. I och med detta inleddes en global ekonomisk era. Det här är en fas som uppmärksammats av Klaus Dörre och Ulrich Brinkmann (2005:99-110) och det är ett utvecklingsskede som representerar

Brigitte Aulenbacher \& Birgit Riegraf: Välfärdsstaten och det ekonomiska sammanbrottet. 
ett fundamentalt brott med fordismen. Till skillnad från den fordistiska modellen av tillgångar, där den realekonomiska utvecklingen (till exempel på kreditmarknaden) understöddes av en ekonomi som på ett sätt förtydligade dess existens, markeras denna fas av en separation mellan de finansiella och de reella ekonomierna. Olika former av kortsiktiga vinster, till exempel genom aktier, hedgefonder, kreditvärderingsinstitut, och slutligen dess kopplingar till bostadsmarknaden, äventyrar de realekonomiska tillgångarna och därigenom stabiliteten på arbetsmarknaden.

Denna utveckling är utmärkande för subsistence welfare under båda faserna, men får störst genomslag från 1990-talet och framåt. Välfärdsstaten som huvudsakligen skattefinansieras utmanas av vinstnedgång, minskat skatteunderlag och ökande åligganden (se Castel 2000, 2003). Det senare kommer från otrygghet på arbetsmarknaden och förändring i levnadsvillkoren, vilket blev tydligt vid den senaste ekonomiska krisen men också av andra utvecklingar, till exempel demografiska förändringar.

Till följd av den ekonomiska krisen, och under den tid som staten har arbetat för att åtgärda och återfå en stark ekonomi, märks en ökande tendens att den offentliga sektorn - och speciellt subsistence welfare ska vara det område som ska balansera den nationella budgeten genom besparingar.

Denna utveckling är en del av en långtgående samhällelig tendens som kan beskrivas som en välfärdskris. Det innebär att det privata och public subsistence welfare, inklusive egenvård, har nedvärderats jämfört med ekonomiska intressen och samti- digt pressats till det yttersta. Resultatet är att överlevnaden både för individen och för samhället som helhet är hotad (se Aulenbacher 2009).

\section{Public subsistence welfare som en konsekvens av NPM}

Inte bara sedan 1990-talet, utan redan under 1980-talet, var alla OECD-länder på olika sätt inriktade mot en omorganisering av den offentliga sektorn i enlighet med principerna om New Public Management, (NPM) (se Riegraf 2007, Tepe, Gottschall \&Kittel 2008). Det ökade införandet av marknadskrafter och ekonomiska mekanismer som styrmedel har till syfte att tillhandahålla samhälleliga offentliga nyttigheter - åtminstone teoretiskt - billigare, med högre kvalitet och på ett mer serviceinriktat sätt än vad som var möjligt med den tidigare statliga byråkratiska organisationen och dess kontrollmekanismer. Program för privatisering, etablerandet av konkurrens mellan privata företag, staten och halvstatliga institutioner, ekonomisk uppföljning, konsulter och offentlig/privat samverkan, innebär att den statliga välfärdsmodellen omskapas (se Riegraf, Kuhlmann \& Theobald 2009, Hood \& Peters 2004). Under tiden har den här utvecklingen påverkat de sociala aktörerna i den tredje sektorn, såsom ideella organisationer (till exempel Röda korset) och kyrkor, som i olika länder deltar i varierande grad för att säkerställa public subsistence welfare. Dessa processer av rationalisering och omorganisering innebär en långtgående omfördelning av ansvar för välfärden mellan markna- 
den, staten och den tredje sektorn. Vidare återspeglas detta även i de privata hushållen som också organiserar sin välfärd på nya sätt (se Aulenbacher 2007, Aulenbacher \& Riegraf 2009).

Principiellt råder det tvivel om i vilken utsträckning omstruktureringen och omorganiseringen av public subsistence welfare $\mathrm{i}$ enlighet med NPM verkligen kan säkerställa en effektivare välfärd som är tillgänglig för alla. Fokus på bilden av mänskligheten som homo economicus, där individen maximerar sina egenintressen, frambringar en bild av vinstgivande företag, och välfärd reduceras till denna idé om duglighet (se Riegraf 2007:83-86). Forskning visar att detta ger upphov till spänningar och påtvingad ojämlikhet, eftersom klienter som är i behov av välfärdsstaten inte har förmåga att hantera de nya kraven enligt dessa ideal, där individen maximerar sina egna intressen (ibid).

Att notera är att den övergripande tendensen till en orientering mot den fordistiska modellen av fasta anställningsförhållanden och enförsörjarfamiljer med en manlig inkomsttagare och en hemmafru i OECD-länderna har gett vika för AdultWorker Model (AWM) ${ }^{4}$ (se Lutz 2010). På samma sätt som arbetsfördelningen mellan marknaden, familjen och staten har varit organiserad på olika sätt i olika länder, har det nu genomförts förändringar för att hantera oron för public subsistence welfare. I länder som Österrike och Tyskland, som anses vara konservativa enligt EspingAndersens modell, har omorganiseringen av public subsistence welfare, eller snarare

4 Adult-Worker Model innebär att både mannen och kvinnan ska ha rätt till heltidsarbete. dess nedrustning, lett till en situation som liknar den liberala modellen i USA, genom det ökande antalet kvinnliga immigranter från Östeuropa och andra utomeuropeiska länder som utför omsorgsarbete i familjen (Bettio et al. 2006, Rerrich 2006, MetzGöckel et al. 2008). Denna utlokalisering och omfördelning av arbetet sker i mindre utsträckning i Sverige och inte i samma form, eftersom familjen stöds av statliga regler utifrån en befintlig - men minskande - offentlig service. Oberoende av dessa skillnader är tendensen tydlig att välfärden i den konkurrensinriktade AWM säkerställs av riktade individuella utbetalningar. Dessutom kan bristen på stöd medföra att nya halvprivata och ibland olagliga bidrag och stödformer mobiliseras eller åtminstone tolereras (se Lutz 2010).

Både bilden av mänskligheten och den ideala människan under NPM, liksom orienteringen av välfärdsstaten mot AWM, innebär en ny uppfattning av statens roll. Enligt Stephan Lessenich (2009:159-174) prioriteras den aktiverande välfärdstaten med den waktiva samhällsmedborgaren" som tar på sig ansvaret att arbeta för sociala förmåner genom egeninsatser eller också att välja bort dessa (se Butterwegge 2007). Det inbegriper att det bakom scenen finns icke-aktiva individer, det vill säga personer som inte uppfattas vara i stånd att längre uppnå aktivt medborgarskap (Lessenich 2009:159-174). Lessenich visar att detta är en fundamental omsvängning från den keynesianska välfärdsstaten, så länge som den marknadsorienterade staten inte kan - och inte förväntas - fullgöra den tidigare formulerade funktionen att balansera den politiska ekonomin, de sociala intressena

Brigitte Aulenbacher \& Birgit Riegraf: Välfärdsstaten och det ekonomiska sammanbrottet. 
och att reglera konflikter. Samhälleliga problem och konflikter har i stället överförts till enskilda individer och har slutligen individualiserats (Lessenich 2009:165-167).

I nästa avsnitt kommer vi att beskriva denna kombination av faktorer med exempel från områdena vård och socialt arbete.

\section{Vård och socialt arbete mellan ekonomisering, avprofessionalisering och nya professionaliseringsformer}

Den sociala utvecklingen och även utvecklingen av den offentliga sektorn kan illustreras genom det sätt på vilket vård och socialt arbete har blivit omorganiserat och omskapat.

Båda dessa tjänstesektorer ingår i en tradition av public subsistence welfare som är extrema i termer av rationalisering, könsarbetsdelning och professionalisering. Robert Castel (2000) har spårat utvecklingen av rationalisering inom vården och det sociala arbetet tillbaka till tiden före industrialiseringen. Först handlade det bara om att statistiskt räkna antalet vårdtagare, senare handlade det om organiserandet av dessa arbetsområden. Dessa båda områden vård och socialt arbete - har sitt ursprung $\mathrm{i}$ kvinnors arbetsområden, $i$ vårdarbete inom den offentliga hälsosektorn och i utvecklingen av den privata sfären. Socialt arbete har sina rötter i medelklassens välgörenhet under slutet av 1800-talet och i 1900-talets regler kring utförandet av socialt arbete. När vårdarbetet utvecklades i semi-professioner fanns det rapporter om en tidig professionalisering av det sociala arbetet.
Vårdarbetet bibehölls som ett kvinnoyrke och det sociala arbetet blev ett område för båda könen, även om det samtidigt blev en tydlig genusskillnad och genushierarki i fördelningen av arbetet på olika chefspositioner samt i fördelningen av ansvar (Bauer \& Büscher 2008, Hammerschmidt \& Sagebiel 2010).

Under fordismen präglas båda dessa områden av rationaliseringssträvanden men också av kritik mot detta. Båda områdena visar under 1900-talets två första årtionden och under efterkrigstiden fram till 1950-talet tydliga rörelser mot att uppnå en högre grad av effektivitet genom att standardisera arbetsrutinerna. De reformer som inleddes under 1960-talet och som fortsatte att utvecklas under 1970talet hängde samman med en kritik om att vård och socialt arbete individualiserade sociala problem, De nya reformerna ger utrymme för strukturella insatser i arbetet med patienter och klienter, där brukaren ses i ett socialt sammanhang och där hela personen med dennes fysiska och psykologiska problem inkluderas. Dessa förändringar är organisatoriskt knutna till utvecklingen av välfärdsstaten (Lessenich 2003).

När den offentliga sektorn rationaliserades under principer från NPM, genomgick både vård och socialt arbete återigen omfattande förändringar jämfört med den tidigare reformorienterade fasen när dessa sektorer växte och dess innehåll omstrukturerades. Socialt arbete och vård organiserades olika beroende på vilken av de olika välfärdsmodellerna som är aktuell: konservativ, liberal eller socialdemokratisk. I den konservativa modellen som vi diskuterar nedan ser vi följande tendenser. 
Den tidigare statligt administrerade organiseringen av vård och socialt arbete förändras nu mot en marknadsekonomisk inriktning. För det första sker det samtidigt genom att tidigare utförare av vård och omsorg - speciellt kommuner, kyrkor och privata välgörenhetsorganisationer - omorganiserar arbetssätt och service. För det andra, och delvis i relation till det tidigare nämnda, genomförs det i nya aktörssammanhang, som samverkan mellan offentlig och privat, eller genom privata företag i konkurrens med offentlig verksamhet.

Inom vård och socialt arbete samverkar minskad professionalisering, olika former av taylorism och ett nytt perspektiv där människan sätts i centrum på ett mer informellt sätt, tillsammans med akademisering och professionalisering av administrativa arbeten och chefstjänster. Parallellt med aktörernas ansträngningar att omorganisera vården och det sociala arbetet, förhåller vi oss till en förändring i den professionella utvecklingen inom dessa områden och av arbetets innehåll. Akademiseringen av dessa områden innebär delvis en återetablering, delvis en omorganisering av vård, socialt arbete och social vetenskap. Ett uttryck för den nya sortens professionalisering är en ökning av yrkesfunktioner inriktade mot uppföljning och kvalitetsutveckling (se Hammerschmidt \& Sagebiel 2010, Mühlum et al. 1997, Wendt 1995, Wilken 2000).

På en diskursiv nivå har det inom socialt arbete funnits kontroverser kring relationen mellan ekonomi och etik, vilket också tar sig uttryck i en generationskonflikt (se Wendt 1995, Wilken 2000). Några av de nu aktiva socialarbetarna och socialpeda- gogerna härstammar från den generation som implementerade dagens reformer som chefer, men är också från den generation vars yrkesstandard skapats under reformernas tid och som nu upplever en identitetskonflikt med det nya som har introducerats (se Wendt 1995). Andra socialarbetare är å andra sidan utbildade under en ny regim. Omorganiseringen av det sociala arbetet är också en motsägelsefull professionell process, eftersom det råder meningsskiljaktigheter kring dess mål och begrepp. Introduktionen av Taylorinspirerade idéer om "case management" leder till att det sker en uppdelning av personorienterat arbete i fallrelaterat arbete och administrativt arbete. Diskussionen har dock gällt ett ökande antal fall.

I termer av avprofessionalisering - särskilt inom omsorg med dess personcentrerade, interaktiva och vardagliga karaktär - har Taylorismens principer och arbetets informalisering lett till att komplexa arbetsuppgifter faller sönder i isolerade småuppgifter (se Gottschall 2008; Kelle 2007). Samtidigt har det skett en utveckling mot akademisering och professionalisering av det administrativa chefsarbetet. Detta hänger i sin tur samman med en nedvärdering av det sociala arbetet och sjukvårdsarbetet som ger dessa en lägre status, vilket i sin tur leder till att man i stället för att anställa professionella eller semi-professionella anställer personal med lägre kvalifikationer. Syftet med att garantera välfärden strider delvis mot ekonomiseringen av det sociala. Trots en utvecklad arbetsstruktur med anställda inom arbetsorganisationen som tar ansvar, kan detta ske informellt. Det är en utveckling som också har givit

Brigitte Aulenbacher \& Birgit Riegraf: Välfärdsstaten och det ekonomiska sammanbrottet. 
upphov till en diskussion om förhållandet mellan ekonomi och etik och som har blivit en offentlig skandal (se Kelle 2007). Detta leder oss över till idéerna om genomförande och social rättvisa.

\section{Idén om genomförande och social rättvisa}

Etableringen av efterkrigstidens fordistiska samhälle, som förde med sig tekniska och ekonomiska innovationer och löften om välstånd, åtminstone för den inhemska manliga medelklassen, åtföljdes av kritik mot dess otyglade marknadsekonomi och diskussioner om lika möjligheter och social rättvisa (se Negt 2001:308-379, Riegraf 2006:259-260, 2006a:324-346, Hirsch 2005 83-113, Riegraf 2005:22-24, 2005a:227-229). I motsats till detta följs den postfordistiska samhällsmodellens utvidgning av en diskussion om marknadens krav, konkurrens och statens tillbakadragande - åtminstone fram till sentida ingrepp på det finanspolitiska området. I den fordistiska modellen är det staten som får ta ansvaret för utvecklandet av jämställdhet och social rättvisa enligt det som tidigare har nämnts, men nu blir det i stället marknaden som ansvarar för social rättvisa och som blir överordnad staten i den frågan. Och detta påverkar även den samhälleliga förståelsen av social rättvisa.

I denna strukturrationalisering av vård och socialt arbete - liksom inom den övriga offentliga sektorn - visar den ekonomiska nyorienteringen en tendens till att empiriska försök från mikroekonomin tillämpas på hela den offentliga välfärden.
Ursprunget till detta är den mikroekonomiska modellen, där enskilda individer ses som isolerade från sitt sociala sammanhang. Social rättvisa skapas alltså av marknadskrafterna - om det ur detta perspektiv överhuvudtaget skapas en social individ.

Tron på marknadskrafterna visar till exempel att medborgare ses som kunder i välfärdsstaten, i den mån det är tillämpligt, något som bygger på tanken om homo economicus. Detta följs av tanken i den mikroekonomiska teorin att den rationella, vinstmaximerade och egoistiska individen i beslutssituationer väljer de mest vinstgivande möjligheterna. Genom valfriheten och alternativa valmöjligheter säkerställs den offentliga välfärden i slutändan genom marknaden. Möjligheterna att handla på olika sätt som ligger bortom denna självcentrering förnekas och blir inte möjlig i detta samhälle där marknadskrafterna styr (se Riegraf 2007:83-86; Riegraf 2007a:260f).

Denna teoretiska konstruktion förutsätter inte bara en fri marknad med obegränsad konkurrens, utan också ett handlande subjekt som är i stånd att räkna ut sina egna behov, som känner till alla tillgängliga möjligheter för att tillgodose sina behov och som är i stånd att värdera alla möjligheter som rör hans eller hennes önskemål i avsikt att eventuellt acceptera - inom ramen för kontraktsfrihet - vilket erbjudande han eller hon föredrar. Människor som inte är i stånd att göra detta på grund av bristfälliga kunskaper, sjukdom, ålderdom eller för låg inkomst eller andra orsaker ingår inte i dessa sammanhang (se Kelle 2007). De som i första hand är i behov av denna vård och 
service och som är beroende av expertkunskap ingår inte $\mathrm{i}$ denna föreställning om humanitet. Konsekvensen blir att de antingen har begränsad tillgång till service eller att tillgången till service kopplas till deras aktivitet och handlande (Lessenich 2009). Det senare gör det intressant att närmare studera hur social rättvisa kommit att förstås som en följd av den pågående omstruktureringsprocessen.

Om fördelningsrättvisa, och fördelning utifrån enskildas behov, var vägledande för den fordistiska modellen, vilket Christoph Butterwegge (2007:136-171) funnit vara fallet i Tyskland, så är rättvisa i den postfordistiska eran baserat på prestation, allt enligt idén om homo economicus. Detta får två konsekvenser för vård och socialt arbete.

För det första består en del av den professionella standarden för vård och socialt arbete i att garantera att välfärdsinsatsen bygger på klientens behov. När det gäller frågan om social rättvisa, innebär professionellt arbete på det här området - mot bakgrund av genus, klass, etnisk bakgrund och andra kriterier - att ojämlikhet definitivt måste beaktas, men att fördelningen och verkställande av tjänster måste följa principen om jämlikhet. I en konstellation där ett stabilt och omfattande utbud av vård- och omsorgstjänster äventyras på grund av rationaliseringar, kommer man att göra hårdare prioriteringar och risken ökar att man inte bara tar hänsyn till olikheter, utan att olika behandling uppmuntras. Dessa prioriteringar, liksom att man ser mellan fingrarna på ojämlik behandling, blir pragmatiska lösningar på dilemmat att rättvisa inte kan skapas för både markna- dens och klientens behov (Aulenbacher \& Riegraf 2007).

För det andra handlar det om att tydligt förstå vad som ska belönas för det som utförs i samhället och exakt vem som ska utföra det, så att båda dessa faktorer kan identifieras tydligt. $\AA$ andra sidan utförs det aktiviteter inom den privata välfärden, inom familjen - arbeten som fortfarande huvudsakligen utförs av kvinnor. Detta ses dock inte som insatser, eftersom de inte är socialförsäkringsgrundande. Detta framgår till exempel i situationer där unga arbetslösa kvinnor med familj får mindre stöd än män i motsvarande positioner (se Rudolph 2009).

\section{Slutsatser}

Rationaliseringarna inom vård och socialt arbete sker mot bakgrund av de förändrade idéerna om social rättvisa. Detta ger upphov till en rättvisa som bygger på utförande vilket - åtminstone $i$ "konservativa" välfärdsregimer - handlar om en specifik föreställning om social ojämlikhet. Den ständiga debatten om ekonomi och etik som kan observeras i sammanhang där vård och socialt arbete ingår, visar att införandet av marknadsprinciper och ekonomiska principer, kravet på tillgängliga och behövande klienter och professionell standard inom vård och socialt arbete, sammanförs på ett konfliktfyllt sätt. En del av den professionella uppgiften inom vård och socialt arbete är att garantera välfärden och att tillhandahålla den utifrån mottagarnas behov. I ett tänkande baserat på marknadens effektivitet äventyras ett stabilt och omfattande tjänsteutbud. Dessa spän-

Brigitte Aulenbacher \& Birgit Riegraf: Välfärdsstaten och det ekonomiska sammanbrottet. 
ningar och motsättningar är uttryck för en välfärdskris som yttrar sig på olika sätt inom olika välfärdsregimer där beslut om insatser kringgärdas av de begränsningar som skapas av finanskrisen och den ekonomiska politik som följer i dess spår.

\section{Litteratur}

Aulenbacher, Brigitte (2007) "Vom fordistischen Wohlfahrts- zum neoliberalen Wettbewerbsstaat, Bewegungen im gesellschaftlichen Gefüge und in den Verhältnissen von Klasse, Geschlecht und Ethnie.» In: Klinger, Cornelia; Knapp, Gudrun-Axeli; Sauer, Birgit (Hg.), Achsen der Ungleichheit - Achsen der Differenz, Verhältnisbestimmungen von Klasse, Geschlecht, Rasse/Ethnizität, Frankfurt/New York: Campus Verlag, S. 46-56

Aulenbacher, Brigitte (2009) "Arbeit, Geschlecht und soziale Ungleichheiten, Perspektiven auf die Krise der Reproduktion und den Wandel von Herrschaft in der postfordistischen Arbeitsgesellschaft." In: Arbeits- und Industriesoziologische Studien (AIS) der Sektion Arbeits- und Industriesoziologie in der DGS, 2. Jg., Heft 2, Dezember 2009, www.ais-studien. de, S. 61-78

Aulenbacher, Brigitte \& Riegraf, Birgit (2009) "Markteffizienz und Ungleichheit - Zwei Seiten einer Medaille? Klasse/ Schicht, Geschlecht und Ethnie im Übergang zur postfordistischen Arbeitsgesellschaft." In: Brigitte Aulenbacher \& Wetterer, Angelika (Hg.), ARBEIT. Perspektiven und Diagnosen der Geschlechterforschung, Münster: Verlag Westfälisches Dampfboot, S. 230-248

Bauer, Ulrich \& Büscher, Andreas (Hg.) (2008) Soziale Ungleichheit in der Pflege, Beiträge sozialwissenschaftlich orientierter Pflegeforschung, Wiesbaden: VS Verlag für Sozialwissenschaften

Beer, Ursula \& Chalupsky, Jutta (1993) „Vom Realsozialismus zum Privatkapitalismus, Formierungstendenzen im Geschlechterverhält- nis." In: Aulenbacher, Brigitte \& Goldmann, Monika (Hg.), Transformationen im Geschlechterverhältnis, Beiträge zur industriellen und gesellschaftlichen Entwicklung, Frankfurt/New York: Campus Verlag, S. 184-230

Bettio, Francesca, Simonazzi, Annamaria \& Villa, Paola (2006) "Change in care regimes and female migration: the care drain in the Mediterranean." In: Journal of European Social Policy, 16, 271-285

Butterwegge, Christoph (2007) »Rechtfertigung, Maßnahmen und Folgen einer neoliberalen (Sozial-)Politik." In: Butterwegge, Christoph; Lösch, Bettina; Ptak, Ralf unter Mitarbeit von Tim Engartner, Kritik des Neoliberalismus, Wiesbaden: VS Verlag für Sozialwissenschaften, S. 135-219

Burau, Viola; Theobald, Hildegard \& Blank, Robert H. (2007) Governing home care. A Cross-National Comparison. Cheltenham: Edward Elgar

Castel, Robert (2000) Die Metamorphosen der sozialen Frage. Eine Chronik der Lohnarbeit, Konstanz: UKV Universitätsverlag

Dölling, Irene (2003) "Zwei Wege gesellschaftlicher Modernisierung. Geschlechtervertrag und Geschlechterarrangements in Ostdeutschland in gesellschafts-/modernisierungstheoretischer Perspektive.» In: Knapp, Gudrun-Axeli; Wetterer, Angelika (Hg.): Achsen der Differenz, Gesellschaftstheorie und feministische Kritik II, Münster: Westfälisches Dampfboot, S. 73-100

Dörre, Klaus \& Ulrich Brinkmann (2005) „Finanzmarktkapitalismus - Triebkraft eines flexiblen Produktionsmodells?" In: Kölner Zeitschrift für Soziologie und Sozialpsychologie (Sonderheft: Finanzmarktkapitalismus. Analysen zum 
Wandel von Produktionsregimen), S. 85-116.

Esping-Andersen, Gosta (1990) The three worlds of welfare capitalism. Cambridge: Polity Press

Gottschall, Karin (2008) "Soziale Dienstleistungen zwischen Informalisierung und Professionalisierung - oder: der schwierige Abschied von deutschen Erbe sozialpolitischer Regulierung." In: Arbeit 4, S. 254-267

Graham, Hilary (1991) »The concept of caring in feminist research: The Case of Domestic Service." In: Sociology, Vol. 24, No.1, 61-78

Hammerschmidt, Peter \& Sagebiel, Juliane (Hg.) (2010) Professionalisierung im Widerstreit, Zur Professionalisierungsdiskussion in der Sozialen Arbeit - Versuch einer Bilanz, Neu-Ulm: AG SPAK

Hirdman, Yvonne (1995), "Gesellschaftliche Planung unter rationaler Kontrolle: Social Engineering in Schweden in den dreißiger und vierziger Jahren.» In: Aulenbacher, Brigitte; Siegel, Tilla (Hg.): Diese Welt wird völlig anders sein. Denkmuster der Rationalisierung, Pfaffenweiler: Centaurus Verlag, S. 31-54

Hood, Christopher \& Peters, Guy (2004) »The middle age of New Public Management. Into the Age of Paradox." In: Journal of Public Administration Research and Theory, Vol. 14, No. 3, S. 267-282

Kelle, Udo (2007) ",Kundenorientierung" in der Altenpflege? Potemkinsche Dörfer sozialpolitischen Qualitätsmanagements," in: PROKLA, Zeitschrift für kritische Sozialwissenschaft, Jg. 37, Nr. 1, S. 113-128

Kohlmorgen, Lars (2004) Regulation, Klasse, Geschlecht. Die Konstituierung der Sozialstruktur im Fordismus und Postfordismus, Münster: Westfälisches Dampfboot

Lessenich, Stephan (Hg.) (2003): Wohlfahrtsstaatliche Begriffe, Grundbegriffe, historische und aktuelle Diskurse, Frankfurt/New York: Campus Verlag

Lessenich, Stephan (2009) „Mobilität und Kontrolle. Zur Dialektik der Aktivgesellschaft." In: Soziologie - Kapitalismus - Kritik. Eine Debatte, Dörre, Klaus; Lessenich, Stephan; Rosa, Hartmur unter Mitarbeit von Thomas
Barth, Frankfurt a.M.: Suhrkamp, S. 126-177

Lutz, Helma (2010) „Unsichtbar und unproduktiv? Haushaltsarbeit und Care Work - die Rückseite der Arbeitsgesellschaft.»In: Aulenbacher, Brigitte; Ziegler, Meinrad (Hg.), Arbeit in Alltag, Biografie, Gesellschaft, Österreichischen Zeitschrift für Soziologie 2, S. 23-27

Metz-Göckel, Sigrid; Morokvasic, Mirjana \& Münst, Senganata A. (Hg.) (2008) Migration and mobility in an enlarged Europe. Leverkusen/Farmington-Hills: Barbara Budrich Publishers

Mühlum, Albert; Bartholomeyczik, Sabine; Göpel, Eberhard (1997) Sozialarbeitswissenschaft, Pflegewissenschaft, Gesundheitswissenschaft, Freiburg i.Br: Lambertus

Negt, Oskar (2001) Arbeit und menschliche Würde, Göttingen: Steidl Verlag

Pfau-Effinger, Birgit (1994) „Erwerbspartnerin oder berufstätige Ehefrau: sozio-kulturelle Arrangements der Erwerbstätigkeit von Frauen im Vergleich."Soziale Welt 45, 322-337

Rerrich, Maria S. (2006) Die ganze Welt zu Hause. Cosmobile Putzfrauen in privaten Haushalten. Hamburg: Hamburger Edition

Riegraf, Birgit (2005) "Staat, Geschlecht und Gerechtigkeit. Theoretische Annäherungen an ein Spannungsverhältnis im Umbruch." In: Femina Politica, Schwerpunktheft: Modernisierung des Wohlfahrtsstaates - Modernisierung der Ungleichheit?, 14. Jg., Heft 2, S. 21-31

Riegraf, Birgit (2005a) »Koordinaten eines gewandelten Staatsverständnisses: Das New Public Management.» In: Groh, Kathrin; Weinbach, Christine (Hg.), Zur Genealogie des politischen Raumes. Politische Strukturen im Wandel, Wiesbaden: VS Verlag für Sozialwissenschaften, S. 225-244

Riegraf, Birgit (2006) „New Public Management als Chance oder Risiko für Geschlechtergerechtigkeit? Eine Analyse der neuseeländischen Reformen." In: Degener, Ursula; Rosenzweig, Beate (Hg.), Die Neuverhandlung sozialer Gerechtigkeit. Feministische Analysen und Perspektiven, Reihe Politik und Geschlecht, Band 18, Wies-

Brigitte Aulenbacher \& Birgit Riegraf: Välfärdsstaten och det ekonomiska sammanbrottet. 
baden: VS Verlag für Sozialwissenschaften, S. 221-238

Riegraf, Birgit (2006a) "Gerechtigkeitskonzeptionen im Wandel: Von der Gleichheit zur Differenz." In: Aulenbacher, Brigitte; Bereswill, Mechthild; Löw, Martina; Meuser, Michael; Mordt, Gabriele;Schäfer, Reinhild; Scholz, Sylka (Hg.), Arbeiten mit der Kategorie Geschlecht. FrauenMännerGeschlechterforschung, Münster: Westfälisches Dampfboot:, S. 323-333

Riegraf, Birgit (2007) „Der Staat auf dem Weg zum Dienstleistungsunternehmen? New Public Management geschlechtsspezifisch analysiert." In: Aulenbacher, Brigitte; Funder, Maria; Jacobsen, Heike; Völker, Susanne (Hg.), Arbeit und Geschlecht im Umbruch der modernen Gesellschaft. Forschung im Dialog, Wiesbaden: VS Verlag für Sozialwissenschaften, S. 78-94

Riegraf, Birgit (2007a) „New Public Management und Geschlechtergerechtigkeit." In: Sonderheft „Normative Grundlagen der Sozialpolitik und der sozialen Sicherung. Gerechtigkeitskonzepte - Religion und Weltbilder - Menschenbilder". In: Zeitschrift Sozialer Fortschritt. Unabhängige Zeitschrift für Sozialpolitik, Jg. 56; H. 9 - 10, S. 259 - 264

Riegraf, Birgit; Kuhlmann, Ellen \& Theobald, Hilde (2009) „Public Sektor Governance in internationaler Perspektive", Schwerpunktheft 'Zeitschrift für Sozialreform', Jg. 55, Heft 4

Riegraf, Birgit \& Theobald, Hilde (2010) „Welfare mix und Geschlechterverhältnis im Wandel. Das Beispiel Altenpflege.» In: Dackweiler,
Regina-Maria; Schäfer, Reinhild (Hg.), Transformationen von Wohlfahrtsstaatlichkeit und Geschlechterverhältnissen aus feministischer Perspektive, Münster: Westfälisches Dampfboot, i. E.

Rudolph, Clarissa (2009) "Arbeitslosigkeit - Bremse oder Motor beim Wandel der Geschlechterverhältnisse?» In: Aulenbacher, Brigitte; Wetterer, Angelika (Hg.), Arbeit, Diagnosen und Perspektiven der Geschlechterforschung, Münster: Westfälisches Dampfboot, S. 138-156

Schweitzer, Sylvie (1995) Des engrenages à la chaine. Les usines Citroen, Ithaka: Cornell University Press

Siegel, Tilla (1993) „Das ist nur rational, Ein Essay zur Logik der sozialen Rationalisierung." In: Reese Dagmar u.a. (Hg.): Rationale Beziehungen? Geschlechterverhältnisse im Rationalisierungsprozess, Frankfurt a.M.: Suhrkamp Verlag, S. 363-396

Tepe, Markus; Gottschall, Karin \& Kittel, Bernhard (2008) "Marktwirtschaftsmodelle und öffentliche Beschäftigungsregimes in der OECD«, In: der moderne Staat 2/2008. S. 377397

Wendt, Wolf Rainer (Hg.) (1995) Soziale Arbeit im Wandel ihres Selbstverständnisses. Beruf und Identität, Freiburg i.Br: Lambertus

Wilken, Udo (Hg.) (2000) Soziale Arbeit zwischen Ethik und Ökonomie, Freiburg i.Br:: Lambertus

Young, Brigitte (1998) "Genderregime und Staat in der globalen Netzwerk-Ökonomie.» In: Prokla 111, S. 175-198 


\section{Summary}

\section{The Financial Meltdown and the Crisis of Reproduction: Imaginations of Performance, Participation and Social Justice}

The task of the Keynesian welfare state in the formation of Fordist society was, among other things, to cushion the powerful effects of the destructive forces of economic crises on societal subsistence welfare. During the recent financial crisis state interventions were also provided, though primarily to subsidize the financial economy and secondly in order to limit the damage to the real economy. Public subsistence welfare is affected by this state intervention insofar as the previously men- tioned investments were partially financed from economies in this area. However, this is just the tip of the iceberg. Public subsistence welfare has been in the process of restructuring for a considerable time. This paper follows this development by relating the current situation to contemporary affairs, by analysing the restructuring process in the public sector, by elaborating on developments in care and social work and by looking at changes in the notions of performance and justice. 